\title{
ISOLAI DAN PENGUKURAN AKTIVITAS ENZIM BROMELIN \\ DARI EKSTRAK KASAR BONGGOL NANAS (Ananas comosus) PADA VARIASI SUHU DAN pH
}

\author{
Mashuri Masri, Dosen Jurusan Biologi, \\ Fakultas Sains dan Teknologi, UIN Makassar, \\ 081342522912, email: mashuriuin@gmail.com
}

\begin{abstract}
Abstrak: Penelitian ini dilakukan untuk mengisolasi enzim bromelin dari bonggol nanas (Ananas comosus) serta mengukur protein dan aktivitas enzim bromelin dengan substrat gelatin. Tahap penelitian meliputi penentuan kadar protein enzim bromelin pada perlakuan pengendapan amonium sulfat berdasarkan konsentrasi 10-60\% serta penentuan aktivitas enzim bromelin pada variasi $\mathrm{pH} 4,0 ; 5,0 ; 6,0 ; 7,0$ dan 8,0, dengan waktu inkubasi selama 10 menit pada suhu $65^{\circ} \mathrm{C}$. Masing-masing tahapan dilakukan tiga kali pengulangan dan dianalisis secara spektrometri. Hasil yang diperoleh memperlihatkan kadar protein tertinggi pada pengendapan dengan amonium sulfat $60 \%$ yaitu sebesar $37,214 \mathrm{mg} / \mathrm{ml}$ dan $\mathrm{pH}$ optimum aktivitas enzim bromelin yaitu pada $\mathrm{pH}$ 7,0 dengan nilai aktivitas 1,081 unit/gram.
\end{abstract}

Kata Kunci: Ananas Comosus, Amonium Sulfat, Ph, Enzim

\section{ISOLAI and MEASURING the ENZYME ACTIVITY of CRUDE EXTRACT BROMELIN PINEAPPLE (Ananas comosus) on pH and TEMPERATURE VARIATIONS}

\begin{abstract}
This study was conducted to isolate the enzyme bromelin from pineapple (Ananas comosus) and measures the protein and enzyme activity of bromelin with gelatin substrate. Phase of the study involves determining the protein content of the enzyme bromelain in the treatment of ammonium sulfate precipitation by $10-60 \%$ as well as the determination of the concentration of the enzyme bromelain activity at $\mathrm{pH} 4.0$ variation; $5.0,6.0 ; 7.0$ and 8.0, with incubation time for 10 minutes at a temperature of $650 \mathrm{C}$. Each stage is done three times repetition and analyzed spectrofotometry. The results obtained showed the highest protein content in ammonium sulfate precipitation with $60 \%$ in the amount of $37.214 \mathrm{mg} / \mathrm{ml}$ and $\mathrm{pH}$ optimum activity of the enzyme bromelin which is the $\mathrm{pH}$ value of 7.0 to the activity of 1,081 units/gram.
\end{abstract}

Keywords: Ananas Comosus, Ammonium Sulfate, Ph, Enzyme 
Nanas termasuk tanaman herba epifit, umumnya memiliki batang pendek. Daunnya panjang dan sempit, umumnya berkumpul di dasar atau merupakan roset, serta memiliki duri. Bunga terminal (Syamsiah, 2006). Nenas termasuk buah buni majemuk, jika bakal buah masing-masing bunga dalam bunga majemuk membentuk suatu buah buni. Pada buah nanas pada pembentukan buah ikut pula mengambil bagian daun-daun pelindung dan daun-daun tenda bunga, sehingga keseluruhannya nampak sebagai satu buah saja. Keseluruhan buah yang bergabung menjadi satu dihubungkan oleh batang tengah yang disebut hati/bonggol (Tjitrosoepomo, 2009). Adapun klasifikasi dari tanaman nenas adalah sebagai berikut:

$\begin{array}{ll}\text { Divisio } & \text { : Magnoliophyta } \\ \text { Classis } & \text { : Liliopsida } \\ \text { Subclassis } & \text { : Zingiberidae } \\ \text { Ordo } & \text { : Bromeliales } \\ \text { Familia } & \text { : Bromeliaceae } \\ \text { Genus } & : \text { Ananas }\end{array}$

Species : : Ananas comosus.

Lembaga Ilmu Pengetahuan Indonesia (LIPI) sejak tahun 70-an telah menyadari, bahwa enzim akan memiliki peranan penting dalam industri. Enzim adalah protein tidak beracun namun mampu mempercepat laju reaksi kimia dalam suhu dan derajat keasaman yang sesuai. Enzim akan menghasilkan produk yang sangat spesifik sehingga dapat diperhitungkan dengan mudah. Pada saat ini dan bahkan di masa yang akan datang, enzim menjadi primadona industri karena melalui penggunaannya, energi dapat dihemat dan akrab dengan lingkungan. Saat ini penggunaan enzim dalam industri makanan dan minuman, industri tekstil, industri kulit dan kertas di Indonesia semakin meningkat (Lipi, 2013).

Bromelin adalah enzim yang diekstrak dari buah nanas (ananas comosus). Bromelin diisolasi dari buah nanas dengan menghancurkan daging buah untuk mendapatkan ekstrak kasar enzim bromelin (Hairi, 2010, 16). Bromelin ini berbentuk serbuk amori dengan warna putih bening sampai kekuning-kuningan, berbau has, larut sebagian dalam aseton, eter, dan $\mathrm{CHCl}_{3}$ (Fajrin, 2012). Penggunaan nama bromelin untuk enzim pemecah protein yang berasal dari nanas sekilas menimbulkan kesan tidak taat asas, karena nama nanas adalah Ananas comosus, walaupun tanaman ini termasuk tanaman Bromeliaceae. Tampaknya, penamaan enzim menurut organisme sumber ini hanya berhasil dilakukan terhadap enzim tumbuh-tumbuhan dan itupun jumlahnya tidak banyak. Bersamaan dengan itu, penggunaan akhiran -in pada nama enzim mulai ditinggalkan dan hanya bertahan pada enzim yang sudah terlanjur dikenal dengan tatanama seperti itu (Sadikin 2002).

Bromelin termasuk ke dalam golongan sufrihidil yang mengandung enzim proteolitik. Selain itu juga mengandung peroksida, asam fosfat, beberapa protease inhibitor, dan organik yang mengikat kalsium. Enzim bromelin menghidrolisis protein 
yang mengandung ikatan peptida menjadi asam amino yang lebih sederhana. Dalam hal ini sistein endopeptidase secara khusus memotong ikatan peptida pada gugus karbonil seperti yang ditemukan dalam ariginin atau asam amino aromatik yaitu fenilalanin atau tirosin (Gautam et al., 2010).

Enzim bromelain termasuk golongan glikoprotein yaitu protein yang mengandung satu bagian oligosakarida pada tiap molekul, yang terikat secara kovalen dengan rantai polipeptida enzim tersebut. Adapun deretan asam amino disekitar lokasi aktifnya :-Cys - Gly - Ala - Cys - Trp-Asn - Gly - Asp - Pro - Cys - Gly - Ala - Cys - Cys - Trp. Sistein (Cys) menunjukkan tempat lokasi aktifnya (Gautam et al., 2010). Berdasarkan beberapa penelitian terdahulu diketahui bahwa nanas beserta limbahnya (batang dan kulit) dapat, menghasilkan enzim bromelin. Enzim ini dapat diisolasi dari daging buah, kulit buah, bonggol (hati), tangkai daun, dan daun (Suhermiyati dan Setyawati, 2005).

Buah nanas yang muda maupun yang tua juga mengandung enzim bromelin. Buah nanas muda mengandung enzim bromelin lebih banyak. Sedangkan buah nanas yang matang enzim bromelin lebih sedikit dibandingkan yang muda (Hairi, 2010). Aktivitas bromelin optimum pada suhu $50^{\circ} \mathrm{C}$, di atas suhu tersebut keaktifan akan menurun. $\mathrm{pH}$ optimum 6,5-7 dimana enzim akan mempunyai konformasi yang mantap dan aktivitas maksimal (Fajrin, 2012).

Bromelin merupakan unsur pokok dari nanas yang penting dan berguna dalam bidang farmasi dan makanan. Fungsi bromelin mirip dengan papain dan fisin, sebagai pemecah protein. Pada akhir-akhir ini enzim bromelin lebih banyak digunakan untuk penjernihan bir ("chillpoofing bir") dan pengempukan daging. Selain itu enzim bromelin sering pula dimanfaatkan sebagai bahan kontrasepsi KB untuk memperjarang kehamilan. Ibu-ibu yang sedang mengandung tidak dianjurkan makan nanas karena dapat mengakibatkan keguguran (Wuryanti, 2004).

Enzim bromelin merupakan enzim protease seperti halnya renin (renet), papain dan fisin yang mempunyai sifat menghidrolisis protein (Effendi, Winarni dan Sumarni, 2012). Hidrolisis yang terjadi dengan enzim protease adalah putusnya ikatan peptida dari ikatan substrat, di mana enzim protease bertugas sebagai katalisator di dalam sel dan bersifat khas (Suhermiyati dan Setyawati, 2005).Uji Bradford merupakan suatu uji dengan tujuan untuk mengukur konsentrasi protein total secara kolorimetri dalam suatu larutan. Pada uji Bradford melibatkan pewarna Coomassie Brilliant Blue (CBB) yang akan berikatan dengan protein dalam suatu larutan. Dari warna yang dihasilkan, secara kolorimetri maka dapat diukur absorbansinya dengan menggunakan spektrofotometri (Lambert-Beer) pada panjang gelombang 465-595 nm (cahaya tampak) (Bradford, 1976).

\section{METODE PENELITIAN}

Penelitian ini merupakan penelitian eksperimen yang mengisolasi enzim bromelin dari bonggol nanas dan mengukur aktivitas enzim bromelin dari bonggol nanas pada variasi $\mathrm{pH}$ untuk mengetahui $\mathrm{pH}$ optimumnya. 
Penelitian ini terdiri atas dua variabel:

1. Variabel terikat yaitu aktivitas enzim bromelin.

2. Variabel bebas yaitu ekstrak buah nanas (Ananas comosus) berdasarkan variasi $\mathrm{pH}$.

1. Enzim bromelin adalah enzim yang diekstrak dari bonggol nanas (Ananas comosus). Satu unit aktivitas enzim didefinisikan sebagai jumlah enzim yang dibutuhkan untuk menghidrolisis substrat gelatin per satuan waktu pada kondisi percobaan.

2. $\mathrm{pH}$ optimum enzim bromelin adalah $\mathrm{pH}$ dengan aktivitas tertinggi enzim bromelin dalam menghidrolisis substrat gelatin

\section{Ruang lingkup}

Buah nanas diperoleh dari pasar Sentral Sungguminasa, Kabupaten Gowa pada bulan Mei 2013. Lokasi penelitian adalah Laboratorium Mikrobiologi dan Fakultas Sains dan Teknologi, Universitas Islam Negeri Alauddin Makassar.

\section{Batasan Penelitian}

Sampel yang digunakan adalah buah nanas yang mengkal dan dilakukan pengamatan sebanyak 3 kali pengulangan. Enzim bromelin dari bonggol nenas akan diukur kadar proteinnya secara spektrofotometri berdasarkan pengendapan amonium sulfat pada konsentrasi 10-60\%, substrat terhidrolisis dan aktivitas enzimnya pada variasi $\mathrm{pH} 4,0 ; 5,0 ; 6,0 ; 7,0$; dan 8,0 dan suhu $65^{\circ} \mathrm{C}$ sesuai dengan hasil optimum yang didapatkan dari penelitian Kumaunang dan Kamu (2011). Untuk menghentikan reaksi dilakukan pemanasan enzim bromelin pada air mendidih selama 10 menit.

Alat yang digunakan pada penelitian ini adalah pisau, baskom, gelas kimia, neraca analitik, sentrifug (Thermo Scientific Haraeus Labofuge 200 Centrifuge), cawan petri, kuvet, tabung Eppendorf, oven (Memmert), pipet tetes, blender (Miyako HM-620), kulkas, corong, vorteks (Barnstead Thermolyne Type 37600 Mixer), inkubator (Thermo Scientific Haraeus Incubator), mikro pipet, hot plate dan Spektrofotometer UV-Visible.

Bahan utama penelitian ini adalah buah nanas diperoleh dari pasar Sungguminasa, kemudian diambil bonggolnya. Selain itu, bahan lainnya adalah: aquades $\left(\mathrm{H}_{2} \mathrm{O}\right)$, natrium asetat $\left(\mathrm{CH}_{3} \mathrm{COONa}\right) 0,1 \mathrm{M} \mathrm{pH} 6,5$, amonium sulfat $\left(\left(\mathrm{NH}_{4}\right)_{2} \mathrm{SO}_{4}\right)$ konsentrasi $10-60 \%$, buffer fosfat $\left(\mathrm{H}_{2} \mathrm{PO}_{4}^{-}\right) 1 \mathrm{M}$ pH 6,5, gelatin, reagen Bradford, kertas saring dan indikator $\mathrm{pH}$ universal.

\section{Pembuatan Ekstrak Kasar Bonggol Buah Nanas}

Isolasi ekstrak bonggol nanas dilakukan berdasarkan metode Gautam, et al. (2010). Bonggol nanas yang digunakan pada penelitian ini yaitu nanas yang masih mengkal, ditandai dengan warna kulitnya hijau kekuningan. Bonggol nanas dicuci dengan aquades, kemudian dipotong kecil-kecil dan ditimbang sebanyak 500 gram. Selanjutnya

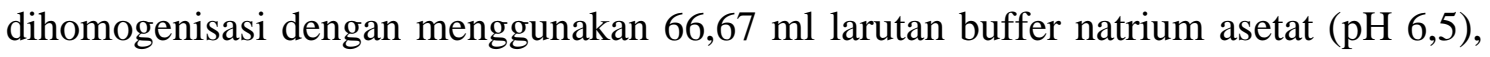
dan kemudian disaring.

\section{Pengendapan dengan Amonium Sulfat}

Presipitasi ekstrak kasar enzim bromelin diadaptasi dari Soares, et al. (2010). Pengendapan dilakukan dengan cara penambahan amonium sulfat sebanyak 10\%, 20\%, 
$30 \%, 40 \%$, 50\% dan 60\%. Masing-masing $7 \mathrm{ml}$ ammonium sulfat ditambahkan $3 \mathrm{ml}$ ekstrak kasar bonggol nanas yang telah disaring sambil diaduk menggunakan pengaduk magnet selama 45 menit. Selanjutnya diinkubasi semalam pada suhu $4^{\circ} \mathrm{C}$ di dalam lemari es. Setelah itu, disentrifugasi pada 3500 rpm selama 25 menit untuk memisahkan ekstrak kasar enzim dari sisa-sisa jaringan nanas. Hasil sentrifugasi akan didapatkan supernatan dan pelet yang merupakan ekstrak kasar enzim bromelin. Pelet yang dihasilkan dicuci dengan $10 \mathrm{~mL}$ buffer natrium asetat $0,1 \mathrm{M}$ pada kisaran $\mathrm{pH}$ 6,5. Pengamatan dilakukan sebanyak 3 kali ulangan.

\section{Penentuan Kadar Protein Ekstrak Enzim Bromelin}

Penentuan kadar protein dilakukan dengan menggunakan metode Bradford (1976, 248-254). Uji Bradford adalah suatu uji untuk mengukur konsentrasi protein total dengan secara kolorimetri dalam suatu larutan. Dalam uji Bradford melibatkan pewarna Coomassie Brilliant Blue (CBB) yang berikatan dengan protein dalam suatu larutan yang bersifat asam sehingga memberikan warna (kebiruan). Karena menghasilkan warna biru maka absorbansi diukur pada $\lambda 595 \mathrm{~nm}$. Kadar protein ditentukan dengan membandingkan absorbansi ekstrak enzim bromelin dengan kurva standar gelatin.

a. Pengukuran Larutan Standar Protein

Sebelum melakukan pengukuran larutan standar protein maka terlebih dahulu dibuat larutan standar protein dengan cara menimbang 0,01 g gelatin kemudian dilarutkan dengan $10 \mathrm{ml}$ aquades steril sehingga diperoleh larutan stok gelatin pada konsentrasi 1000 ppm. Larutan stok pada konsentrasi 1000 ppm diencerkan dengan melarutkan 0,5 ml larutan stok ditambahkan 4,5 ml aquades steril sehingga diperoleh larutan stok gelatin $100 \mathrm{ppm}$. Dari larutan stok tersebut dilakukan pengukuran terhadap standar protein terlarut dengan konsentrasi 10, 20, 30, 40, 50 dan 60 ppm. Kemudian dilakukan pengukuran terhadap standar protein dengan menambahkan $0,05 \mathrm{ml}$ seri larutan standar dengan 2,5 $\mathrm{ml}$ reagen Bradford. Pengamatan dilakukan dengan 3 kali pengulangan. Kemudian larutan divortex dan di inkubasi pada suhu ruang selama 10-60 menit. Larutan ini memberikan warna biru dan selanjutnya diukur absorbansinya pada $\lambda 595 \mathrm{~nm}$.

b. Pengukuran Protein Terlarut

Pengukuran sampel dilakukan dengan cara $0,5 \mathrm{ml}$ seri ekstrak enzim kasar ditambahkan dengan 2,5 $\mathrm{ml}$ reagen Bradford divortex lalu diinkubasi pada suhu ruang selama 10-60 menit. Pengamatan dilakukan 3 kali pengulangan. Absorbansi larutan sampel protein selanjutnya diukur pada $\lambda 595 \mathrm{~nm}$.

\section{Penentuan pH Optimum Enzim Bromelin}

Sebanyak $0,125 \mathrm{ml}$ gelatin ditambahkan dengan $0,5 \mathrm{ml}$ buffer asam fosfat $1 \mathrm{M}(\mathrm{pH}$ 6,5) dan 0,125 gram ekstrak enzim bromelin yang telah dikeringkan dalam oven selama 15 menit pada suhu $50^{\circ} \mathrm{C}$. Selanjutnya larutan diinkubasi pada suhu $65^{\circ} \mathrm{C}$ selama 10 menit pada nilai pH yakni : 4,0; 5,0; 6,0; 7,0; 8,0. Pengamatan dilakukan 3 kali pengulangan. Reaksi dihentikan dengan pemanasan pada air mendidih selama 10 menit. Setelah itu, absorbansi diukur pada $\lambda 595 \mathrm{~nm}$ dengan menggunakan spektrofotometer. 
Penentuan kadar protein ditentukan dengan membandingkan absorbansi ekstrak enzim bromelin dengan persamaan linear kurva standar gelatin. Sedangkan aktivitas enzim bromelin dapat ditentukan dengan rumus di bawah ini:

$$
\text { Aktivitas Enzim }=\text { Substrat Terhidrolisis } x \frac{1}{\text { BM Enzim }} \times \frac{\text { Volume Larutan }}{\text { Berat Enzim }}
$$

Dimana: BM Enzim = $\quad 181.19 \mathrm{~g} / \mathrm{mol}$ (Ishak, 2012, 66)

\section{HASIL DAN PEMBAHASAN}

\section{Pengukuran Kadar Protein Enzim Bromelin pada Variasi 10-60 \% Amonium Sulfat}

Pengukuran kadar protein enzim bromelin dari ekstrak bonggol nanas diberikan perlakuan yaitu bonggol nanas yang telah disaring akan ditambahkan larutan amonium sulfat dengan variasi $10 \%, 20 \%, 30 \%, 40 \%, 50 \%$ dan $60 \%$ lalu diinkubasi agar enzim bromelin akan terendapkan. Adapun kadar protein yang diperoleh pada pengendapan amonium sulfat ini dapat dilihat pada tabel 1

Tabel 1. Kadar Protein Bromelin dari Ekstrak Bonggol Nanas pada Variasi Konsentrasi Amonium Sulfat.

\begin{tabular}{|c|c|c|c|c|c|c|}
\hline $\begin{array}{c}\text { Konsentrasi } \\
(\%)\end{array}$ & $\mathrm{U} 1(\mathrm{~nm})$ & $\mathrm{U} 2(\mathrm{~nm})$ & $\mathrm{U} 3(\mathrm{~nm})$ & $\begin{array}{c}\text { Jumlah } \\
(\mathrm{nm})\end{array}$ & Rata-rata $(\mathrm{nm})$ & $\begin{array}{c}\text { Kadar protein } \\
(\mu \mathrm{g} / \mathrm{ml})\end{array}$ \\
\hline 10 & 0,974 & 0,974 & 1 & 2,948 & 0,983 & 36,357 \\
\hline 20 & 1 & 1 & 1 & 3 & 1 & 36,964 \\
\hline 30 & 1 & 1 & 1 & 3 & 1 & 36,964 \\
\hline 40 & 1 & 0,94 & 1 & 2,94 & 0,980 & 36,250 \\
\hline 50 & 1 & 1 & 1 & 3 & 1 & 36,964 \\
\hline 60 & 1 & 1 & 1,02 & 3,02 & 1,007 & 37,214 \\
\hline
\end{tabular}

Keterangan:

$\mathrm{U} 1=$ ulangan $1 . \mathrm{U} 2=$ ulangan $2 . \mathrm{U} 3=$ ulangan 3

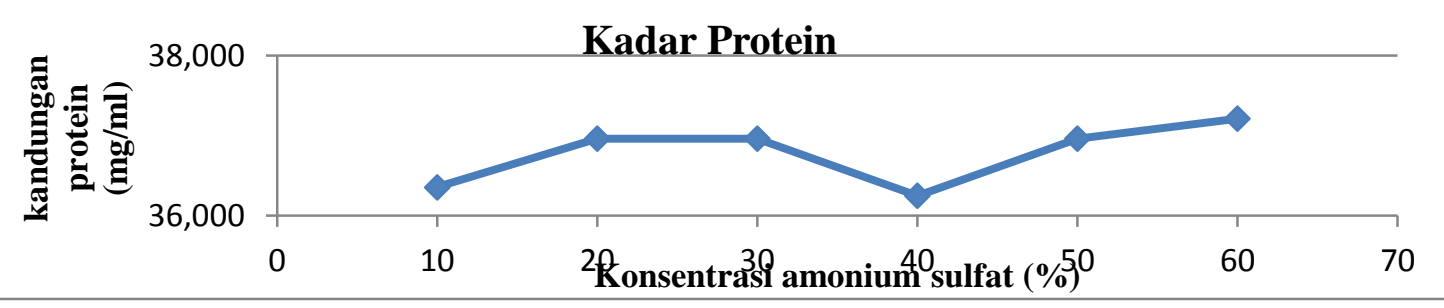

Gambar 1. Grafik Pengaruh Konsentrasi Amonium Sulfat terhadap Pengendapan Protein

\section{Pengukuran Aktivitas Enzim pada Variasi pH}

Aktivitas enzim bromelin diukur berdasarkan kemampuannya menghidrolisa substrat gelatin pada suhu inkubasi $65^{\circ} \mathrm{C}$. Pengukuran dilakukan secara spektrofotometri pada panjang gelombang $595 \mathrm{~nm}$. Hasil pengukuran yang diperoleh dapat dilihat pada tabel 2 
Tabel 2. Pengukuran Aktivitas Bromelin dari Ekstrak Bonggol Nanas pada Variasi pH

\begin{tabular}{|r|r|r|r|r|r|r|}
\hline $\mathrm{pH}$ & \multicolumn{1}{|c|}{$\begin{array}{c}\mathrm{U} 1 \\
(\mathrm{~nm})\end{array}$} & $\begin{array}{c}\mathrm{U} 2 \\
(\mathrm{~nm})\end{array}$ & \multicolumn{1}{c|}{$\begin{array}{c}\mathrm{U} 3 \\
(\mathrm{~nm})\end{array}$} & \multicolumn{1}{c|}{$\begin{array}{c}\text { Rata-rata } \\
(\mathrm{nm})\end{array}$} & $\begin{array}{c}\text { Substrat } \\
\text { terhidrolisis } \\
(\mathrm{g} / \mathrm{ml})\end{array}$ & $\begin{array}{c}\text { Aktivitas enzim } \\
\text { (unit/g) }\end{array}$ \\
\hline 4 & 1 & 1 & 1 & 1 & 36,964 & 1,020 \\
\hline 5 & 0,996 & 1,002 & 1,006 & 1,001333 & 37 & 1,021 \\
\hline 6 & 1,004 & 1,025 & 0,998 & 1,009 & 37,286 & 1,029 \\
\hline 7 & 0,983 & 1,005 & 1,199 & 1,062333 & 39,179 & 1,081 \\
\hline 8 & 0,994 & 0,01 & 1,007 & 0,670333 & 25,179 & 0,695 \\
\hline
\end{tabular}

$\mathrm{U} 1=$ ulangan $1 . \mathrm{U} 2=$ ulangan $2 . \mathrm{U} 3=$ ulangan 3

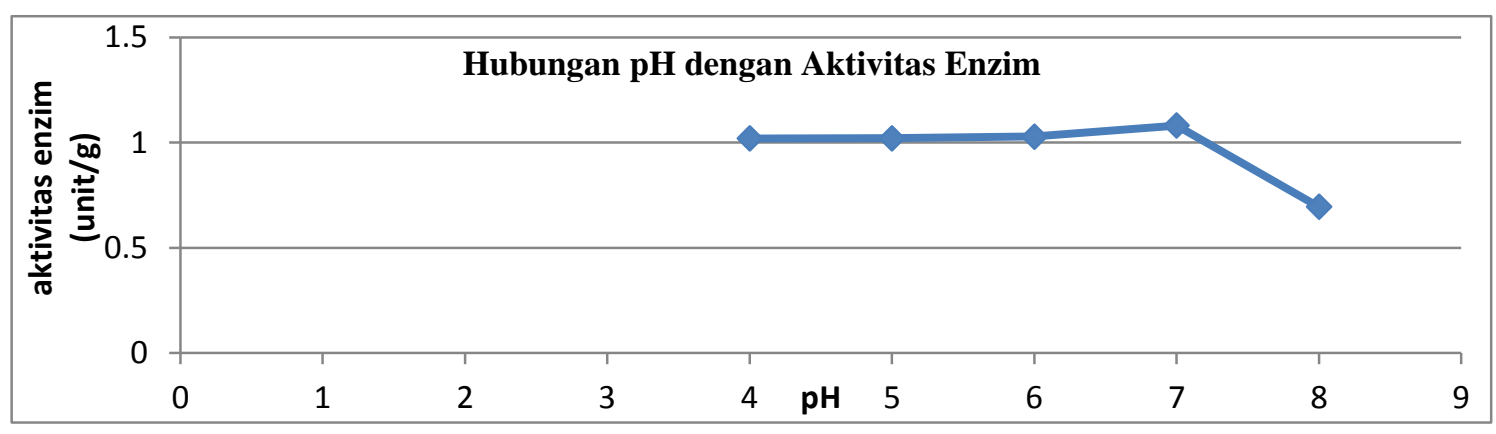

Gambar 2. Grafik Pengaruh pH terhadap Aktivitas Enzim Bromelin

Enzim bromelin adalah enzim yang diekstrak dari buah nanas (ananas comosus). Bromelin termasuk ke dalam golongan sufrihidil yang mengandung enzim proteolitik. Selain itu juga mengandung peroksida, asam fosfat, beberapa protease inhibitor, dan organik yang mengikat kalsium. Enzim bromelin menghidrolisis protein yang mengandung ikatan peptida menjadi asam amino yang lebih sederhana. Dalam hal ini sistein endopeptidase secara khusus memotong ikatan peptida pada gugus karbonil seperti yang ditemukan dalam arginin atau asam amino aromatik yaitu fenilalanin atau tirosin (Gautam et al., 2010, 75). Dalam penelitian ini substrat yang digunakan yaitu gelatin. Gelatin merupan protein yang mengandung 19 asam amino yang dihubungan dengan ikatan peptida termasuk arginin dan tirosin (Hajrawati, 2006, 8).

Jika ekstrak kasar enzim bromelin telah didapatkan maka selanjutnya ekstrak akan diukur kadar proteinnya dengan membandingkan absorbansi ekstrak enzim bromelin dengan kurva standar gelatin. Kadar protein enzim bromelin dari ekstrak kasar bonggol nanas diukur dengan menggunakan spektrofotometer. Spektrofotometer akan menentukan kadar protein baik secara kuantitatif maupun kualitatif dengan mengukur transmitan ataupun absorban larutan blanko ataupun pembanding. Dari hasil pembacaan spektrofotometer pada $\lambda 595 \mathrm{~nm}$ maka diperoleh kurva standar gelatin dengan persamaan regresi $\mathrm{y}=0,028 \mathrm{x}-0,035$.

\section{Pengukuran Kadar Protein Enzim Bromelin pada Variasi 10-60 \% Amonium Sulfat}

Amonium sulfat berfungsi untuk mengendapkan protein bromelin tanpa ikut mengendapkan protein nonbromelin. Selain itu, ammonium sulfat juga menghasilkan 
peningkatan kemurnian bromelin. Beberapa protein berbeda kelarutannya dalam konsentrasi garam yang berbeda. Pengendapan dengan amonium sulfat dapat dilakukan pada konsentrasi 10-100 \%. Semakin tinggi konsentrasi amonium sulfat maka pengendapan protein semakin baik namun pengendapan dengan amonium sulfat terdapat titik kejenuhannya. Menurut Soares, et al. $(2010,3)$ pengendapan protein enzim bromelin dengan amonium sulfat dari ekstrak kasar daging buah paling baik pada konsentrasi 40 $\%$ namun jika sudah berada pada konsentrasi 60-100 \% maka pengendapannya semakin berkurang dikarenakan larutan protein mengalami titik kejenuhan.

Pada penelitian ini digunakan variasi amonium sulfat 10-60\% untuk mengendapkan enzim bromelin. Hasilnya belum didapatkan titik kejenuhan amonium sulfat untuk mengendapkan enzim bromelin dari bonggol nanas namun pengendapan tertinggi terjadi pada konsentrasi $60 \%$ dengan kadar protein 37,214 $\mu \mathrm{g} / \mathrm{ml}$. Hal ini menandakan konsentrasi $60 \%$ mencapai titik isolistrik protein yang diinginkan. Pada titik isolistrik kelarutan protein berkurang non bromelin hingga minimum dan protein yang diinginkan akan mengendap, sedangkan protein lain yang tidak diinginkan tetap dalam larutan.

Pengendapan tersebut dapat terjadi karena adanya persaingan antara garam dan protein untuk mengikat air. Ion-ion pada protein mengikat banyak molekul air dengan sangat kuat. Namun ion-ion garam memiliki densitas muatan yang lebih besar dibandingkan protein sehingga garam dapat lebih mengikat molekul air. Menurunnya jumlah air yang terikat pada protein menyebabkan gaya tarik menarik antara molekul protein lebih kuat bila dibandingkan dengan gaya tarik menarik anatara molekul protein dan air (mempertinggi interaksi hidrofobik), sehingga protein akan mengendap dari larutan atau berikatan dengan kolom hidrofobik.

\section{Pengukuran Aktivitas Enzim Bromelin pada Variasi pH}

Pada penelitian ini didapatkan aktivitas tertinggi berada pada $\mathrm{pH} 7,0$ yaitu 1,081 unit/g dengan substrat terhidrolisis sebesar 39,179 $\mu \mathrm{g} / \mathrm{ml}$. Dari bentuk kurva pada gambar 4.4, tampak bahwa pH optimum dari aktivitas enzim bromelin dari ekstrak kasar bonggol nanas berada pada $\mathrm{pH} 7,0$. Hal ini menandakan bahwa pada $\mathrm{pH}$ 7,0 enzim mempunyai konformasi yang paling sesuai dengan substrat gelatin sehingga dapat membentuk kompleks enzim-substrat yang tepat (Puspita, 2005, 147-151). Pada pH optimum terjadi perubahan ionisasi dalam gugus ionik enzim pada sisi aktifnya atau pada sisi lainnya yang secara tidak langsung mempengaruhi sisi aktif. Gugus pemberi dan penerima proton berada dalam tingkat ionisasi yang diinginkan, sehingga konformasi sisi aktif menjadi efektif dalam mengikat dan mengubah substrat menjadi produk (Nielsen et al., 1999, 105).

Pada $\mathrm{pH}$ 4,0; 5,0; 6,0; dan 8,0 aktivitas enzim lebih rendah dibandingkan dengan $\mathrm{pH}$ 7,0 hal ini dikarenakan pada $\mathrm{pH}$ yang lebih rendah atau lebih tinggi aktivitas enzim akan menurun, rantai samping beberapa asam amino berperan sebagai asam atau basa lemah yang melakukan fungsi kritis pada sisi aktif enzim sehingga enzim menjadi inaktif. 
Hal ini menyebabkan perubahan $\mathrm{pH}$ mengakibatkan perubahan intramolekuler dari enzim (Lehninger, 2009, 240). Selain itu penurunanan aktivitas enzim juga dipengaruhi oleh lingkungan disekitar sisi aktif enzim mengalami kekurangan jumlah proton (Wiradikusumah, 2001, 46).

Pada umumnya aktivitas maksimum enzim berada pada kisaran $\mathrm{pH}$ optimum 4,58,0. pH optimum enzim bromelin dari ekstrak kasar bonggol nanas berbeda dengan $\mathrm{pH}$ optimum enzim bromelin yang didapatkan dari ekstrak kasar batang nanas. Menurut Nurhidayah $(2013,48)$ pH optimum enzim bromelin dari ekstrak kasar dari batang nanas berada pada $\mathrm{pH} 6$ sedangkan $\mathrm{pH}$ optimum enzim bromelin yang diisolasi dari ekstrak kasar bonggol nanas berada pada $\mathrm{pH}$ 7. Hal tersebut dikerenakan sumber enzim diisolasi dari organ yang berbeda meskipun enzimnya sama. Menurut Winarmo $(1986,92)$ enzim tertentu mempunyai kisaran $\mathrm{pH}$ optimum yang sangat sempit. Di sekitar $\mathrm{pH}$ optimum mempunyai stabilitas yang tinggi. Dalam hal ini, enzim yang sama sering kali $\mathrm{pH}$ optimumnya berbeda tergantung dari sumber enzim tersebut.

\section{KESIMPULAN}

Adapun kesimpulan yang didapatkan pada penelitian ini yaitu:

1. Semakin tinggi konsentrasi amonium sulfat maka semakin banyak kadar protein enzim bromelin dari bongol nanas yang diendapkan. Pada penelitian ini konsentrasi $60 \%$ menghasilkan kadar protein yang tertinggi yaitu $37,214 \mu \mathrm{g} / \mathrm{ml}$.

2. $\mathrm{pH}$ lingkungan sangat mempengaruhi aktivitas enzim bromelin dari bonggol nanas $\mathrm{pH}$ rendah atau $\mathrm{pH}$ tinggi dapat menyebabkan terjadinya proses denaturasi dan ini akan mengakibatkan menurunnya aktivitas enzim. Pada penelitian ini jumlah aktivitas enzim dari pH 4,0 sampai pH 7,0 mengalami kenaikan sedangkan di $\mathrm{pH}$ 8,0 sudah mengalami penurunan. $\mathrm{pH}$ optimum enzim bromelin yang diekstrak dari bonggol nenas berada pada $\mathrm{pH} 7,0$ dengan substrat terhidrolisis sebesar $39,179 \mu \mathrm{g} / \mathrm{ml}$ dan aktivitas enzim sebesar 1,081 unit/g.

\section{SARAN}

1. Isolasi enzim bromelin dapat dilakukan pada organ lain dari buah nenas.

2. Penelitian selanjutnya dapat digunakan kisaran variasi $\mathrm{pH}$ yang sempit.

\section{DAFRAR PUSTAKA}

Bradford, M. M.. 1976. A rapid and sensitive method for the quantitation of microgram quantities of protein utilizing the principle of protein-dye binding. Georgia: Anal Biochem University of Georgia.

Gautam., et al. 2010. Comparative study of extraction, purification and estimation of bromelain from stem and fruit of pineapple plant. India: Thai J. Pharm. Sci. 34.

Fajrin, Eni. 2012. Penggunaan Enzim Bromelin Pada Pembuatan Minyak Kelapa (Cocos Nucifera) Secara Enzimatis. Skripsi. Makassar: Universitas Hasanuddin. 
Hairi, Muhammad. 2010. Pengaruh Umur Buah Nanas Dan Konsentrasi Ekstrak Kasar Enzim Bromelin Pada Pembuatan Virgin Coconut Oil Dari Buah Kelapa Typical (Cocos nucifera L.) skripsi. Malang: Jurusan Kimia Fakultas Sains Dan Teknologi Universitas Islam Negeri Maulana Malik Ibrahim Malang.

Hajrawati. 2006. Sifat fisik dan kimia gelatin tulang sapi dengan Perendaman asam klorida pada konsentrasi Dan lama perendaman yang berbeda. Bogor: Institut Pertanian Bogor.

Ishak, Meilty Christy. 2012. Pengaruh Proses Pengeringan dan Imobilisasi Terhadap Aktivitas dan Kestabilan Enzim Bromelin dari Buah Nana (Ananas comosus) skripsi. Makassar: Jurusan Teknologi Pertanian Universitas Hasanuddin.

Lehninger, Albert. L. 2009. Dasar - Dasar Biokomia. Jilid 1; Penerjemah Maggy Thenawijaya. Jakarta: Erlangga.

LIPI. Enzim. Pusat Penelitian Bioteknologi. http://www.biotek.lipi.go.id/index.php?option=com_content $\&$ view=article\&id= 36:Enzim\&catid=51\&Itemid=55. (11 Januari 2011).

Nielsen, et al. 1999. Electrostatics in in the active site of an $\alpha$-amylase. Eur. J. Biochem., 246, 816-824.

Nurhidayah. Isolai dan Pengukuran Aktivitas Enzim Bromelin dari Ekstrak Kasar Batang Nanas (Ananas comosus) Pada Variasi Suhu dan pH. 2013, 48.

Sadikin, Moh, H. 2002. Biokimia Enzim. Jakarta: Widya Medika.

Soares, Paulo et al., Studies on Bromelain Precipitation by Ethanol, Poly (Ethylene Glycol) and Ammonium Sulphate. Brazil: Universidade de São Paulo, 2010. http://www.method-of-bromelai-extraction.pdf. (19 Mei 2013).

Suhermiyati, sri dan Sylvia Josephina setyawati. Potensi Limbah Nanas untuk Peningkatan Kualitas Limbah lkan Tongkol sebagai Bahan Pakan Unggas. ANIMAL PRODUCTION, September 2008, hlm. 174-1 78 ISSN 141 1 - 2027 Terakreditasi No.56lD11<TI/I<epl2005. Vol. 10. No. 3. Purwokerto: Fakultas pertenakan universitas jenderal sudirman, 2008. http://www.adobe.com/10307174178.pdf. (11 Januari 2013).

Syamsiah. 2006. Taksonomi Tumbuhan Tinggi. Makassar: Universitas Negeri Makassar.

Puspita A. 2005. Determination of Optimum Condition of Papain Enzyme from Papaya var Java (Carica papaya). International Journal Chemistry. 5(2).

Tjitrosoepomo. 2009. Gembong. Morfologi Tumbuhan. Yogyakarta: Gadjah Mada University Press.

Winarno, F. G. 1986. Pangan. Jakarta: Gramedia.

Wirahadikusumah, Muhammad. 2001. Biokimia Protein, Enzim dan Asam Nukleat. Bandung: ITB. 